Uniwersytet Warszawski

\title{
Terroryzm jako zakłócona komunikacja. Koncep- cja rozumu komunikacyjnego Jurgena Habermasa a możliwość dialogu po 11 września
}

\section{Terrorism as a distorted communication. The idea of communicative mind of Jurgen Habermas and possibil- ity of dialogue after 11 th September}

$22 / 2017$

Political Dialogues

DOI: http://dx.doi.org/10.12775/DP.2017.008

\begin{abstract}
:
The purpose of the text is to point out the fragments of Jurgen Habermas' thoughts about terrorism, which can be considered as a disturbed communication. Habermas orders to get rid of all serious atavisms, including terrorism. In his view, it is necessary to return to the understanding of politics as a communicational exchange aimed at reaching a rational settlement. In this approach, politics is difficult to distinguish from communication in everyday interactions. In both instances lying, manipulation and fraud cannot dominate, because they expel rational communication. In the following article, I make an attempt to show that Habermas thinks that our goal should be to make social communication more effective, and thus move away from terrorist threats.
\end{abstract}

Słowa kluczowe: Habermas, terroryzm, komunikacja, filozofia, racjonalność

Keywords: Habermas, terrorism, comunication, philosophy, rationality
Teoria działania komunikacyjnego uważana jest za największe osiagnięcie Jurgena Habermasa ${ }^{1}$. Dzieło to rozpowszechniło takie pojęcia jak "system”, „świat życia”, „działanie komunikacyjne” i „rozum komunikacyjny”, które sa obecnie podstawowymi elementami słownika filozofii i nauk społecznych. Celem tej książki, jak i innych mniejszych prac Habermasa oscylujących wokół tego tematu jest wystapienie przeciwko pesymizmowi teorii krytycznej (Habermas przez niektórych badaczy zaliczany jest do tzw. „drugiego pokolenia frankfurtczyków”) i zbudowanie własnej emancypacyjnej koncepcji społecznej2. Zdaniem Alexandre Dupeyrix jednym $z$ powodów, dla którego autor Teorii działania komunikacyjnego w swych badaniach skierował się ku komunikacji i jezzyku jest element biograficzny. Habermas dwukrotnie przeszedł operację zajęczej wargi, czego trwa-

${ }^{1}$ Takie jest zdanie m.in. Alexandre Dupeyrix - zob. A. Dupeyrix, Zrozumieć Habermasa, przeł. M. N. Wróblewska, Warszawa 2013, s. 41.

${ }^{2}$ A. Szahaj, M. N. Jakubowski, Filozofia polityki, Warszawa 2008, s. 106-110. 
łym następstwem jest wada wymowy. To doświadczenie uwrażliwiło go na społeczną naturę życia ludzkiego i pozwoliło mu zrozumieć współzależność ludzkich stosunków i komunikacyjną, językową naturę tych relacji ${ }^{3}$.

Koncepcja działania komunikacyjnego Habermasa jako punkt wyjścia zakłada, że tego, kim jesteśmy uczymy się na podstawie relacji $z$ innymi, a najbardziej podstawowa relacja jest komunikacja za pomoca języka. Istotą dyskusji jest wzajemne zrozumienie, jednak aby była ona owocna po stronie mówiacego i słuchajaccego musi być podjęte zobowiąanie o tym, że będa mówić prawdę i mieć na myśli dokładnie to, co mówią. Dzięki temu taka komunikacja jest praktyka racjonalną i pozwala na osiagniecie konsensus ${ }^{4}$.

Celem niemieckiego filozofa jest rekonstrukcja warunków powodujących, że komunikacja jest efektywna i produktywna zarówno $\mathrm{w}$ aspekcie indywidualnym i społecznym. Odtworzenie tych kryteriów dostarcza narzędzia krytycznego, dzięki któremu można oceniać rzeczywistość społeczna i jej komunikacyjne zakłócenia ${ }^{5}$.

W swoim tekście chciałbym się zastanowić jak XXI-wieczny terroryzm wpływa na teorię działania komunikacyjnego. Dla tego celu najpierw zreferuję najważniejsze punkty koncepcji rozumu komunikacyjnego, a następnie pokrótce przedstawię to, jak Habermas rozumie terroryzm. W podsumowaniu zrekonstruuje habermasowskie recepty na dia$\log z$ terroryzmem i zastanowię się nad możliwościa zastosowania ich $\mathrm{w}$ życiu społecznym i politycznym.

3 A. Dupeyrix, op. cit., s. 13-14.

${ }^{4}$ G. Borradori, Filozofia $w$ czasach terroru. Rozmowy $z$ Jurgenem Habermasa $i$ Jacques'em Derrida, przeł. A. Karalus, M. Kilanowski, B. Orlewski, red. A. Szahaj, Warszawa 2008, 74-75.

5 Ibidem, s. 76.
Koncepcja rozumu komunikacyjnego stworzona przez Habermasa w dobie permanentnego ataku skierowanego przeciw rozumowi ludzkiemu jest obroną nowoczesności, która wiąże się z wyłonieniem autonomicznej i publicznej sfery dyskusji ${ }^{6}$. Filozofia niemieckiego myśliciela w przeciwieństwie do jego poprzedników ze szkoły frankfurckiej zakłada, że mamy do czynienia nie tylko $z$ działaniem ukierunkowanym na cel (rozum instrumentalny i funkcjonalny), ale także $z$ działaniem komunikacyjnym, poprzez które dążymy do dobrowolnego porozumienia. Proponowane przez $\mathrm{Ha}-$ bermasa pojęcie racjonalności związane jest już nie tyle $z$ poznaniem przyrody, władaniem nią (racjonalność kognitywno-instrumentalna) i samozachowaniem systemu (racjonalność instrumentalna), ale także $z$ intersubiektywnością, czyli możliwościa porozumienia (racjonalność normatywnokomunikacyjna) ${ }^{7}$. W Teorii działania komunikacyjnego Habermas stwierdza: „Punkt ogniskowy analizy przesuwa się tym samym $z$ racjonalności kognitywno-instrumentalnej ku racjonalności komunikacyjnej. Paradygmatem dla tej ostatniej jest nie odniesienie samotnego podmiotu do czegoś w świecie obiektywnym, co można przedstawiać i czym można manipulować, lecz stosunek intersubiektywny, w jaki podmioty zdolne do działania i mówienia wchodza wówczas, gdy się ze sobą co do czegoś porozumiewaja"8. Jednakże trzeba zaznaczyć, że celem niemieckiego filozofa

${ }^{6}$ H. Schnadelbach, Próba rehabilitacji animal rationale, przeł. K. Krzemieniowa, Warszawa 2001, s.298-325.

7 D. Sepczyńska, Problematyczny status prawdy w polityce. Strauss - Rawls - Habermas, Kraków 2015, s.218.

8 J. Habermas, Teoria działania komunikacyjnego. Racjonalność działania a racjonalność spoŁeczna, t. 1, przeł. A. M. Kaniowski, przekład przejrzał M. J. Siemek, Warszawa 1999, s. 639-640. 
nie jest uczynienie $z$,intersubiektywności alfy i omegi całego doświadczenia ludzkiego"9, ale możliwie pełne wykorzystanie krytycznego potencjału tego ujęcia do badania rzeczywistości społecznej.

Habermas zaznacza, że pojęcie racjonalności komunikacyjnej może zostać wypracowane jedynie poprzez rozjaśnienie własności formalnych działania skierowanego na porozumienie. Życie społeczne, polityczne i ekonomiczne nie jest związane wyłącznie $z$ próbami coraz doskonalszego opanowania przyrody czy instrumentalna rywalizacja $z$ innymi. Zdaniem autora Teorii działania komunikacyjnego uspołecznienie równie mocno uwarunkowane jest poprzez umożliwienie wszystkim uczestnikom dyskusji osiągnięcia satysfakcjonującego porozumienia $^{10}$.

Według Habermasa język zorientowany jest na porozumienie, a zrozumieć czyjąś wypowiedź, to pojąc rację, które za sobą niesie. Każdy użytkownik języka ma kompetencje jezzykowa, a także szerszą od niej kompetencję komunikacyjna, która wykracza poza sferę języka. Habermas wyróżnia cztery roszczenia do ważności aktów mowy: roszczenie do zrozumiałości, do wiarygodności, do prawdziwości oraz do słuszności normatywnej. Żeby dyskurs spełniał wymogi rozumności musi być realizowany w określonych warunkach. Idealna sytuacja komunikacyjna zakłada symetryczność partnerów, co oznacza, że w dyskursie każdy ma te same prawa, wymogi przedstawiania argumentacji, krytyki i obrony swoich racji ${ }^{11}$.

Komunikacja jest możliwa wyłącznie dzięki temu, że rozumiemy racje, które umożliwiają normatywną ocenę tej wy-

${ }_{9}$ A. Dupeyrix, op. cit., s. 43.

${ }_{10}$ D. Sepczyńska, op. cit., s. 218.

${ }_{11}$ A. Szahaj, M. N. Jakubowski, op. cit., s. $108-109$. powiedzi. Czyli jeśli rozmówca nie przerywa mi i nie dopytuje kiedy wypowiadam jakieś zdanie, to oznacza, że zgadza się z roszczeniem do prawdy zawartym w mojej wypowiedzi. Oczywiście należy pamiętać, że komunikacja nie jest zdaniem Habermasa przestrzenia wolna od konfliktów. Wręcz przeciwnie - jest miejscem permanentnie powstajacych watpliwości. Do racjonalnego porozumienia można dojść jedynie poprzez odwoływanie się do lepszego argumentu, a nie za sprawa groźby, przymusu, na mocy tradycji czy odgórnego zobowiązania. Poprzez to, że jest wykorzystywany do manipulacji, instrumentalizacji i propagandy język staje się miejscem ciagłych nieporozumień. Dlatego może stać się przyczyną konfliktów i niejasności, które jednak w procesie komunikacji można przezwyciężyć. Co więcej, język skierowany jest nie tylko na wzajemne porozumienie, ale także umożliwia lepsze zrozumienie. Wedle koncepcji zawartej w Teorii działania komunikacyjnego doświadczanie konfliktów i sporów komunikacyjnych pozwala poszerzać horyzonty poznawcze. Habermas zdaje sobie sprawę, że rozmówcy moga nie przestrzegać „etyki dyskursu” i kierować się złą wolą, jednak trzeba pamiętać, że jego koncepcja to model racjonalnej komunikacji, a nie empiryczny opis. Celem niemieckiego filozofa jest wskazanie, że język zawiera w sobie praktyczną racjonalność umożliwiajaca porozumienie $^{12}$. Do wątku błędów w komunikacji powrócę jeszcze przy omawianiu habermasowskiej recepty na dialog $z$ terroryzmem.

Według Habermasa rozum komunikacyjny jest publicznym rozumem, który dąży do stworzenia podstaw formalnej debaty i negocjacji. Jest fundamentem życia publicznego w demokracji, można

${ }^{12}$ A. Dupeyrix, op. cit., s. 41-48. 
nawet stwierdzić, że jest „samorozumieniem demokracji" ${ }^{13}$. W pracy Faktyczność $i$ obowiazywanie Habermas stwierdza, że: „Teoria dyskursowa bierze rachubę wyższego stopnia intersubiektywności procesów dochodzenia do porozumienia, które dokonują się poprzez procedurę demokratyczna lub komunikacyjną sieć politycznych sfer publicznych"14.

Celem rozumu komunikacyjnego nie jest motywowanie i kierowanie wolą. Zdaniem Habermasa kryzys komunikacji powoduje kryzys społeczny, konflikty, dezintegracje, a w ostateczności nawet delegitymizację władzy. Intersubiektywność rozumu komunikacyjnego umożliwia wolne od przemocy i jakichkolwiek innych represji porozumienie ${ }^{15}$. W Teorii działania komunikacyjnego niemiecki filozof stwierdza: „Struktury rozumu, do których Adorno jedynie czyni aluzje, stana się dostępne analizie dopiero wówczas, gdy ideę pojednania i wolności odczytamy jako zaszyfrowany wyraz pewnej, choćby i najbardziej utopijnej formy intersubiektywności, która umożliwia na równi wolne od przemocy porozumienie między indywiduami w ich wzajemnych kontaktach oraz tożsamość indywiduum, które bez przemocy dochodzi do porozumienia $z$ samym soba - a zatem umożliwia uspołecznienie bez represji"16.

Racjonalność komunikacyjna zdaniem Habermasa ma dostarczać skutecznych metod kontroli rzeczywistości społecznej. Autor Teorii działania komunikacyjnego jest zdecydowanym krytykiem instrumentalnego wykorzystywania argumentacji, która miałaby służyć

${ }_{13}$ D. Sepczyńska, op. cit., s. 220.

${ }^{14} \mathrm{~J}$. Habermas, Faktyczność $i$ obowiazywanie. Teoria dyskursu wobec zagadnien prawa $i$ demokratycznego państwa prawnego, przeł. A. Romaniuk, R. Marszałek, Warszawa 2005, s. 317-318.

${ }^{15}$ D. Sepczyńska, op. cit., s. 222.

$16 \mathrm{~J}$. Habermas, Teoria działania komunikacyjnego, t. 1, s. 639. do manipulacji zachowaniami ludzkimi. W takiej sytuacji racjonalność instrumentalna przekształca się w dążąca do panowania racjonalność polityczną. Powstaje wtedy stosunek hierarchiczny, co jest niezgodne $z$ podstawa koncepcji Habermasa, czyli wspominana już symetrycznością uczestników dyskusji ${ }^{17}$.

Jak taki teoretyk społeczeństwa obywatelskiego i rozumu komunikacyjnego jak Habermas odnosi się do wydarzeń 11 września i następujących po nich kolejnych atakach terrorystycznych? Aby odpowiedzieć na to pytanie najpierw muszę pokrótce zreferować habermasowka próbę rekonstrukcji terroryzmu, jego podstaw, motywów i celów.

Trzy miesiace po atakach terrorystycznych na World Trade Center i Pentagon w 2001 roku, Habermas w wywiadzie udzielanym Giovannie Borradori stwierdził, że „11 września mógłby być nazwany pierwszym światowym historycznym wydarzeniem w najściślejszym znaczeniu: uderzenie, eksplozja, powolny upadek - wszystko to nie było już hollywoodzka produkcja, lecz budzaca zgrozę rzeczywistość, dosłownie działo się przed globalna publicznościa, na oczach powszechnych świadków naocznych"18. Niemiecki filozof zawraca uwage na zupełnie odmienne oblicze wydarzenia $z 11$ września w porównaniu chociażby do wojny w Zatoce z 1991 roku. Autor Teorii działania komunikacyjnego wskazuje, że konflikt zbrojny w Zatoce Perskiej pokazywany był publiczności w bardzo znikomych dawkach, ograniczano ilość zdjęć i materiałów wideo, przez co obywatele otrzymywali jedynie medialny twór, a nie rzetelna korespondencję. Z kolei dziesięć lat później globalna publiczność stała się

17 T. Maślanka, Racjonalność i komunikacja. Filozoficzne podstawy teorii społecznej Jurgena Habermasa, Warszawa 2011, s. 114-116.

${ }^{18}$ Ibidem, s. 56-57. 19 
„powszechnym świadkiem” terroru, relacje na żywo $z$ tych dramatycznych wydarzeń były transmitowane na żywo na całym świecie. Nigdy wcześniej obywatele świata nie otrzymali tak dużej i zarazem przerażającej dawki rzeczywistości z ekranów telewizora, to sprawia, że 11 września można nazwać przełomem i „pierwszym światowym wydarzeniem historycznym" 19 .

Zdaniem Habermasa zamach z 2001 roku bliższy jest wydarzeniom sierpnia 1914 roku niż atakowi na Pearl Harbor. To dlatego, że podobnie jak wybuch pierwszej wojny światowej, tak 11 września „oznaczał koniec spokojnej i raczej ufnej epoki, poczatek ery wojny totalitarnej opresji". W obu przypadkach panowało niejasne poczucie strachu i grozy. Odpowiedź Stanów Zjednoczonych na terroryzm spowodowała fundamentalny brak zaufania do obcokrajowców, a także oczekiwanie bezwarunkowego wsparcia ze strony politycznych partnerów, czyli zjawiska podobne, do tych które miały miejsce po wybuchu pierwszej wojny światowej ${ }^{20}$.

Habermas zauważa, że bezwarunkowe wsparcie, o które zabiegały Stany Zjednoczone u swoich sprzymierzeńców po 11 września jest sprzeczne $z$ kantowska koncepcją Oświecenia. Dla autora Krytyki czystego rozumu Oświecenie oznacza wyzwolenie się ludzkości od ślepego posłuszeństwa względem autorytetu, które zastapione jest przez racjonalna autoafirmację.

Dlatego też gdyby przyjać perspektywę Kanta - co zdaniem Borradori stara się czynić Habermas - należałoby odrzucić każde żądanie bezwarunkowego wsparcia $^{21}$.

\footnotetext{
19 Ibidem, s. 78.

20 Ibidem, s. 54-55.

${ }^{21}$ Ibidem, s. 80.
}

Według Habermasa można wyodrębnić trzy rodzaje terroryzmu: chaotyczne walki partyzanckie, paramilitarna partyzantke i terroryzm globalny. Model pierwszy charakterystyczny jest dla terroryzmu palestyńskiego, którego główna bronią sa ataki samobójcze. Model drugi określa przede wszystkim walki ruchów narodowowyzwoleńczych dążących do utworzenia własnego państwa. Natomiast model trzeci, czyli terroryzm globalny, zdaniem Habermasa nie ma realistycznych celów politycznych i polega jedynie na wykorzystaniu słabości przeciwnika. Dlatego też ma niewielka szansę na bycie postrzeganym jak ruch polityczny, albo chociaż jako ruch wysuwajacy racjonalne roszczenia polityczne. Niemiecki filozof twierdzi, że: „globalny terroryzm jest ekstremalny zarówno w swym braku realistycznych celów, jak i w swym cynicznym wyzysku wrażliwości złożonych systemów"22.

Habermas podkreśla, że terroryzm należy zaliczyć do innej kategorii niż zbrodnie, które rozpatrywane sa przez sędziego sądu karnego. Terroryzm $\mathrm{w}$ przeciwieństwie do prywatnego incydentu wymaga zainteresowania publicznego i co się z tym wiąże odmiennej analizy. Oczywiście wśród aktów terroru można znaleźć takie, które sa skierowane ku osiagnięciu konkretnego celu politycznego - np. przejęcie władzy. Jednak zdaniem Habermasa ataki na WTC i Pentagon takiego uzasadnienia nie miały. Dlatego też niemiecki filozof we wcześniej już wspominanym wywiadzie powiedział: „dziś nie mogę sobie wyobrazić kontekstu, który by pewnego dnia, w jakiś sposób, czynił potworną zbrodnię 11 września zrozumiałym lub pojmowalnym działaniem politycznym" ${ }^{23}$. Ha-

\footnotetext{
22 Ibidem, s. 62-63, 85.

${ }^{23}$ Ibidem, s. 63.
} 
bermas zaznacza także, że $z$ moralnego punktu widzenia nie ma żadnego wytłumaczenia dla aktów terrorystycznych, ocena etyczna tych czynów zawsze będzie negatywna, motywy i sytuacja nie mają najmniejszego znaczenia ${ }^{24}$.

Podsumowujac, zdaniem Habermasa globalny terroryzm nie ma żadnych realistycznych politycznych celów, więc może być sklasyfikowany jedynie jako bezprawna przemoc. Warto więc zadać sobie pytanie: jak $z$ taka przemoca może poradzić sobie społeczeństwo komunikacyjne? Habermas zdaje sobie sprawę $z$ tych trudności: „Od 11 września byłem często pytany, czy w świetle tego gwałtownego zjawiska cała koncepcja „działania komunikacyjnego", którą rozwinałem w mojej teorii, nie została skompromitowana" ${ }^{25}$. Wydaje mi się, i będę się starał to wykazać, że terrorystyczna spirala przemocy zwiazana jest $z$ tym, że teorii niemieckiego filozofa nie dano okazji do wykazania się, nie wprowadzono jej w życie.

Przede wszystkim Habermas przyznaje, że przemoc nie omija żadnego społeczeństwa: „My na Zachodzie żyjemy w pokojowych i zamożnych społeczeństwach, w których mimo to panuje strukturalna przemoc (do której do pewnego stopnia przywykliśmy), niezmiernie wielka nierówność społeczna, degradujaca dyskryminacja, pauperyzacja i marginalizacja" ${ }^{26}$. Jednak istotne jest to, że wewnatrz demokratycznych, zachodnich społeczeństw ta przemoc jest jedynie strukturalna, a nie fizyczna. Zdaniem Habermasa dzieje się tak dlatego, że „koordynacja działania dokonuje się

24 „Nic nie uzasadnia, byśmy „zgadzali się” na zbrodnię lub cierpienie innych ze względu na czyjś własny interes. Każda zbrodnia to o jedna za dużo.", Ibidem, s. 63.

${ }^{25}$ G. Borradori, op. cit., s. 64.

${ }^{26}$ Ibidem. tutaj za pomoca zwyczajnych gier językowych, poprzez wzajemnie podnoszone i przynajmniej w domniemaniu uznawane roszczenia ważnościowe $\mathrm{w}$ przestrzeni publicznej bardziej lub mniej dobrych racji”27. Nasze życie społeczne ukształtowane jest przez praktyki komunikacyjne pozwalające zrozumieć siebie nawzajem. W ten sposób, według Habermasa akceptujemy reguły kultury, społeczeństwa i wspólnoty, w której funkcjonujemy. Dzięki temu realizuje się postulat symetryczności uczestników dyskursu. Problem pojawia się wtedy, gdy mówiący i słuchający staja się dla siebie obcy, nie chca się słuchać i nawzajem nie uznaja roszczeń do ważności. To jest początek zakłóceń w komunikacji, których ekstremalna, ostateczną wersja może być terroryzm ${ }^{28}$.

Terroryzm zdaniem Habermasa jest patologia komunikacji: „spirala przemocy zaczyna się wraz z zakłóceniem komunikacji, które prowadzi poprzez spirale niekontrolowanego wzajemnego braku zaufania aż do załamania się komunikacji”29. Niemiecki filozof zwraca uwagę, że w zachodnich demokratycznych państwach liberalnych istnieja sposoby, dzięki którym można łagodzić często pojawiajace się załamania komunikacyjne. Przykładowo jeżeli problem jest wewnątrz jednostki rozwiązać go można poprzez wizytę $\mathrm{w}$ gabinecie terapeuty, natomiast $\mathrm{w}$ przestrzeni publicznej instancja rozstrzygajaca sa sady.

Paliwem nakręcającym spiralę przemocy komunikacyjnej staje się potęgujaca zniekształcenia i podziały globalizacja. Zdaniem Habermasa bez politycznego poskromienia nieograniczonego kapitalizmu, tworzącego segregacje niszczące

\footnotetext{
27 Ibidem.

28 Ibidem, s. 93

29 Ibidem, s. 64.
} 
światowe społeczeństwa sytuacja nie ulegnie zmianie. Według autora Teorii działania komunikacyjnego tak zwana „wojna kultur" jest jedynie zasłona maskująca materialne interesy świata zachodniego, co powoduje, że zapomina się o dyskryminacji, poniżaniu i obrazie innych kultur. Świat dzieli się na zwycięzców i przegranych, komunikacja między jedynymi i drugimi ulega całkowitemu zerwaniu. Podział społeczeństw na bogate i biedne leży u podstaw upadku dialogu i jedynym rozwiazaniem tej sytuacji jest odbudowa kanałów komunikacyjnych i próba zrozumienia swoich perspektyw. Habermas twierdzi, że „w związku $z$ tym normatywne samookreślenie się vis-a-vis innych kultur staje się ważne także dla nas. $\mathrm{W}$ procesach takiej rewizji swego własnego wizerunku świat zachodni mógłby się nauczyć, na przykład, jak musiałby zmienić swoją politykę, jeśli chce być postrzegany jako siła kształtująca, mająca wpływ na cywilizację. Bez politycznego poskromienia nieograniczonego kapitalizmu, podział dewastujący światowe społeczeństwa nie zostanie zmieniony"30.

Według Habermasa, aby rozwiązać te trudności ludzie muszą stopniowo, krok po kroku poszerzać swoje perspektywy i w przyszłości je połączyć. Taka „fuzja horyzontów" jest możliwa tylko, gdy strony przyjma rolę słuchajacych lub mówiących. Wcielając się $\mathrm{w}$ te dialogiczne pozycje angażuja się w wymagana przy każdym użyciu mowy - fundamentalna symetryczność. Zdaniem Habermasa, $\mathrm{w}$ trakcie takiego wzajemnego brania pod uwage swoich perspektyw można wykształcić wspólny horyzont podstawowych założeń i osiagnnąc interpretację, która nie jest etnocentryczna a intersubiektywnie podzielana ${ }^{31}$. Co istotne takie

30 Ibidem, s. 65.

31 Ibidem, s. 66. próby maja szanse tylko pod warunkiem, że bierze się pod uwagę perspektyw drugiej strony. Dobre intencje i brak jawnej przemocy na pewno sa pomocne, ale nie wystarczą. Bez odpowiedniej struktury sytuacji komunikacyjnej, która jest wolna od zakłóceń będą pojawiać się zastrzeżenia, że rezultaty zostały wymuszone. Jednak Habermas podkreśla, że „kiedy komunikację opisuje się w taki sposób, gdy nie dostrzega się w niej „nic innego” prócz przemocy, pomija się istotną kwestię: że ogromny wysiłek, by powstrzymać przemoc bez powielania jej w kolejnych aktach przemocy, może być podjęty tylko ze względu na telos wzajemnego zrozumienia i naszego zorientowania na ten cel"32.

Kolejną forma asymetrii, którą wskazuje Habermas sa opóźnienia rozwoju społecznego, ekonomicznego i kulturowego. Zachód narzuca na inne kraje własne, modernistyczne wzorce zbyt szybko, co prowadzi do niszczenia tożsamości. Państwa trzeciego świata tak naprawdę nic nie zyskuja, a nawet nie otrzymuja "uchwytnej rekompensaty” za utratę swoich tradycyjnych form życia. Zamiast stopniowego procesu sekularyzacji wywołuje to "uczucie poniżenia”, blokujące jakiekolwiek zmiany ${ }^{33}$. Jeżeli komunikacja byłaby autentycznym procesem argumentacji wyżej wymienione czynniki, czyli rozwój kulturowy, społeczny i ekonomiczny nie powinny jej uniemożliwiać. Jednak jeżeli asymetria trwa, to znaczy, że jest podtrzymywana przez instrumentalne, wręcz manipulatorskie stosowanie języka, które skierowane jest wyłącznie na realizację egoistycznych celów. Rozmówca nie jest postrzegany jego równo-

32 Ibidem.

33 J. Habermas, Przyszłość natury ludzkiej. Czy zmierzamy do eugeniki liberalnej?, przeł. M. Łukasiewicz, Warszawa 2003, s. 102-104; A. Dupeyrix, op, cit,, s. 200-201. 
wartościowa jednostka, tylko jako środek, dzięki któremu możemy uzyskać zaplanowane korzyści ${ }^{34}$.

Zrozumienie tych przeszkód jest podstawowym warunkiem umożliwiajacym ustanowienie autentycznego dialogu między społeczeństwami wywodzącymi $z$ różnych kultur. Zdaniem Alexandre Dupeyrix w koncepcji Habermasa istotny jest punkt dojścia procesu argumentacji, a nie punkt wyjścia, gdyż tym może być nawet sytuacja niezrozumiała. Istota teorii niemieckiego filozofa jest możliwość zmierzania ku lepszemu zrozumieniu. Jak to ują Dupeyrix: „W rzeczy samej, by wyciagnać wniosek o radykalnej niemożliwości komunikacji pomiędzy ludźmi, trzeba by doświadczyć dyskusji i argumentacji trwającej do końca przestrzeni i czasu!"35.

Żeby dialog mógł być udany konieczna jest chęć obu stron do zaangażowania się w hermeneutyczna refleksję, polegajaca na interpretowaniu i tłumaczeniu elementów składajacych się na tradycję i kulture drugiego. Teoria Habermasa zastosowana do dialogu międzykulturowego wymaga krytycznego interpretowania własnych, politycznych i społecznych doświadczeń. Podejście niemieckiego filozofa jest odmienne chociażby od koncepcji Richarda Rorty'ego, Alasdaira MacIntyre'a i Johna Rawlsa. Podstawa teorii Habermasa jest teza która głosi, że wszystkie podmioty zdolne do mówienia i działania nie mogą się nie uczyć. Według autora Teorii działania komunikacyjnego dialog między kulturami nie ma polegać na porzucaniu przez jedna ze stron swoich poglądów, nie proponuje on także sprowadzania wszystkiego do wspólnego mianownika (jak zasada „częściowego konsensusu" Rawlsa). Habermasowska

\footnotetext{
${ }^{34}$ A. Dupeyrix, op. cit., s. 201-202.

${ }^{35}$ Ibidem, s. 202.
}

filozofia odwołuje się do hermeneutycznego poszerzania kognitywnych i moralnych horyzontów. W trakcie takiego dialogu międzykulturowego możliwe byłoby wypracowanie wspólnych interpretacji i orientacji aksjologicznych ${ }^{36}$.

Komunikacyjne podejście do różnic wynikających $z$ odmienności kulturowych pozwala także rozjaśnić kontrowersje zwiazane $z$ problematyka praw człowieka. Gdy zrozumiemy, że indywidualizacja i socjalizacja sa dwiema stronami medalu, to przeciwstawianie modelu zachodniego (indywidualistycznego) i wschodniego (kolektywistycznego) stanie się bezpodstawne ${ }^{37}$.

Autor Teorii działania komunikacyjnego zwraca uwage, że do spełnienia obietnicy moralnej, która implicite w sobie zawieraja prawa człowieka konieczne sa środki jurystyczne. Dlatego też można stwierdzić, że prawa człowieka maja podwójne oblicze, jedno zwrócone ku moralności, a drugie ku prawu. Mimo że ich treść jest wyłącznie natury moralnej, to maja one formę pozytywnego prawa podmiotowego opatrzonego sankcjami. Zdaniem Habermasa dopiero moralne uzasadnienie i idea godności człowieka połaczone w prawo stanowione moga utworzyć dobrze prosperujace prawa człowieka.

Według autora Uwzgledniajac Innego: „pojęcie praw człowieka nie jest moralnego pochodzenia, lecz jest specyficznym wyrażeniem nowoczesnego pojęcia praw podmiotowych. Tym, co nadaje im pozór praw moralnych, jest nie ich treść, ani tym bardziej ich struktura, lecz sens obowiązywania, który wykracza poza porządki prawne państw narodowych"38.

36 Ibidem, s. 3-205.

37 Ibidem, s. 205.

38 J. Habermas, Uwzględniając Innego. Studia do teorii politycznej, przeł. A. Romaniuk, Warszawa 2009, s. 
Habermas podkreśla, że pojęcie praw człowieka jest wyrażaniem nowoczesnego pojęcia praw podmiotowych, czyli podmiotowości prawnej. Wynika $z$ tego, że prawa człowieka ze swej istoty sa prawnej natury, a tym co nadaje im pozór praw moralnych nie jest ich treść, czy struktura, ale sens obowiazywania, który wykracza poza porządek prawny poszczególnych państw narodowych.

Co istotne, według Habermasa prawa człowieka nie powinny być sprawa polityki, a należy je wprowadzić w system praw i procedur. Zdaniem niemieckiego filozofa takie podejście pozwoli ocalić normatywna treść praw człowieka i obroni je przed manipulacjami, stosowaniem ich do doraźnych interesów, jak i błędnymi interpretacjami. Jako przykład takich działań Habermas wskazuje hegemoniczna politykę prezydenta Stanów Zjednoczonych Georga W. Busha, który starał się moralizować swoje działania wojenne powołujac się na prawa człowieka. Zdaniem Habermasa taka polityka zamiast działać zgodnie $z$ prawem dąży do „uetycznienia” stosunków międzynarodowych ${ }^{39}$. Z kolei takie działania uaktywniają krytyków praw człowieka, mówiących o relatywizmie, arbitralności i fałszywym uniwersalizmie tej koncepcji. Wśród tego rodzaju krytyków wyróżniajacca postacia jest Carl Schmitt, który twierdzi, że przeforsowywanie praw człowieka musi nieuchronnie prowadzić do fundamentalizmu. Według autora Teologii politycznej prawa człowieka sa wyrazem grupowych i partykularnych interesów nowożytnego mieszczaństwa, dla którego ideałem jest oparte na liberalnej konstytucji państwo prawa. Co się z tym wiąże, zdaniem Schmitta prawa człowieka tak naprawdę nie wyrażaja interesów człowieka jako takiego, ale wyłącznie li-

\footnotetext{
39 Ibidem.
}

beralnego mieszczaństwa, który dzięki nim chce się obronić przed obciążeniami nakładanymi przez państwo ${ }^{40}$.

Jednak zdaniem Habermasa jest to rozumowanie opierajace się na błędnej przesłane głoszącej, że prawa człowieka sa prawami moralnymi, co według autora Teorii działania komunikacyjnego nie jest prawda. Wedle Habermasa „fundamentalizmu praw człowieka nie uniknie się poprzez rezygnację $z$ polityki praw człowieka, ale przez wynikajaca $z$ zasady obywatelstwa światowego transformację stanu natury między państwami w stan prawny"41.

Zdaniem Habermasa konstytucjonalizacja międzynarodowego porządku prawnego jest elementem kosmopolityzacji życia, czyli sposobem na utrzymanie i rozwijanie porządku światowego, który pozwoliłby uniknać kolejnych ataków terrorystycznych, albo przynajmniej zmniejszyłby ich prawdopodobieństwo. Co istotne integracja w kierunku społeczeństwa postnarodowego nie zakłada konieczności powstania narodu europejskiego, ale raczej sieci komunikacyjnej w europejskiej sferze politycznej i publicznej, której podstawa powinno być społeczeństwo obywatelskie, złożone z różnych grup interesów i pojedynczy obywateli. Dlatego też patriotyzm konstytucyjny proponowany przez autora Faktyczności $i$ obowiazywania to nie pozytywistyczne zasady konstytucyjne, ale pewne abstrakcyjne formy i sposoby interpretacji spajajace określona zbiorowość. Takimi uniwersalnymi zasadami moga być procedury suwerenności (de-

40 P. Bala, A. Wielomski, Prawa człowieka - refleksje krytyczne, "Wrocławskie Studia Erazmiańskie", Wrocław 2010, z. 4, s. 457-487, tu: s. 467 .

${ }^{41}$ J. Habermas, Uwzględniajac Innego, s. 202-203 . 
mokracji jako zbiorowości) oraz liberalne prawa jednostki (prawa człowieka) ${ }^{42}$.

Według niemieckiego filozofa nie da się zbudować silnej i zjednoczonej Europy na samym poczuciu identyfikacji kulturowej i historycznej (takie myślenie Habermas nazywa mityczna koncepcja wspólnoty europejskiej). Jedyną odpowiedzią może być patriotyzm konstytucyjny, czyli uniwersalizm zasad prawnych określanych przez konsensus proceduralny (oparty na pełnej swobodzie wypowiedzi), osadzony w danej kulturze politycznej. Co istotne patriotyzm konstytucyjny wymaga, aby polityka skupiała się wokół norm wartości i procedur demokratycznych, a nie kultur narodowych; ma za zadanie gwarantować stabilność oraz ochronę podstawowych zasad $^{43}$. Habermas podkreśla, że aby kultura polityczna mogła spajać społeczeństwo konieczne jest zapewnienie wszystkim obywatelom nie tylko wolnościowych praw liberalnych i praw demokratycznej partycypacji, ale także przynajmniej minimum praw socjalnych, kulturowych i społecznych ${ }^{44}$.

Do realizacji dobrze prosperującego patriotyzmu konstytuującego niezbędna jest ogólnoeuropejska sfera publiczna (analogiczna do sfery publicznej wcześniej przeze mnie pokrótce opisywanej), czyli sieć dla komunikowania treści i stanowiska, a więc opinii. Co niezwykle ważne demokracja europejska nie ma być rozszerzoną demokracja narodowa, lecz ma stanowić efekt komunikacji między poszczególnymi publicznym sferami

${ }^{42}$ G. J. Wąsiewski, Koncepcja „patriotyzmu konstytucyjnego" Jurgena Habermasa. W kregu poszukiwań modelu ustrojowego Unii Europejskiej, Toruń 2010, s. 130-132.

${ }^{43}$ Ibidem, s. 133-135.

${ }^{44} \mathrm{~J}$. Habermas, Wizja godności człowieka i realistyczna utopia praw człowieka, [w:] Tegoż, Rzecz o ustroju i kondycji Europy, Łódź 2014, s. 13-43, tu: s. $18-21$. narodowymi tworząc sferę europejska. Mimo wielu takich głosów (chociażby Alexandre Dupeyrix $)^{45}$ Habermas nie jest zwolennikiem utworzenia rządu, czy też państwa światowego, a nawiazujac do Kanta postuluje utworzenie globalnego społeczeństwa światowego ${ }^{46}$.

Habermas zauważa, że Kant wprowadza do teorii prawa trzeci wymiar, obok prawa państwowego i międzynarodowego pojawia się w jego koncepcji - prawo obywateli świata. Według owej wykładni wewnątrz państwowy stan prawny powinien uzyskać ostateczne zwieńczenie $\mathrm{w}$ jednoczacym wszystkie narody globalnym stanie prawnym. Nawiazujac do filozofii Kanta, Habermas postuluje zniesienie stanu natury, który panuje między narodami, analogicznie do tego, jak miało to miejsce podczas pierwszego „wyjścia ze stanu natury”, czyli pierwotnej umowy społecznej obowiazując wewnątrz państwa ${ }^{47}$. Jednakże Habermas w pewnych aspektach wykazujac jej ahistoryczność, zmodyfikował koncepcje przedstawiona przez królewieckiego filozofa. Zdaniem autora Faktyczności i obowiazywania prawo obywatelstwa światowego trzeba zinstytucjonalizować tak, żeby pod groźba sankcji wiązało poszczególne rzady, gdyż dopiero w taki sposób suwerenne państwa będą mogły utworzyć federację wspólnych reguł. Kolejna, jakże istotna zmiana jest rozumienie stanu obywatelstwa światowego nie tyle jako federację państw, ale jako federację obywateli. Dzięki temu każda jednostka

45 „Jeśli chodzi o instytucjonalna formę, jaka miałaby przybrać Unia, Habermas zdaje się skłaniać ku stworzeniu europejskiego państwa federalnego", A. Dupeyrix, op. cit., s. 195.

${ }^{46} \mathrm{~J}$. Habermas, Kantowska idea wiecznego pokoju - z historycznego dystansu 200 lat, [w:] Uwzgledniajac Innego. Studia do teorii politycznej, s. 167-203, tu: s. 180-182.

47 Ibidem, s. 167-170. 
byłaby zarazem obywatelem państwa, jak i świata ${ }^{48}$.

W swoich tekstach dotyczacych sytuacji międzynarodowej Habermas proponuje "wewnętrzna politykę globalna bez światowego rządu". Koncepcja ta miałaby się opierać na trzech demokratycznie legitymizowanych poziomach: ponadnarodowym (organizacja wzorowana na ONZ), transnarodowym (zgromadzenia kontynentalne, takie jak Unia Europejska) i narodowym. Taka wielopoziomowa konstrukcja ma zdaniem Habermasa umożliwić „światowe społeczeństwo ukonstytuowane politycznie bez rzadu światowego" oparte na ponad-państwowej konstytucji prawa narodów, czyli na prawie pozytywnym, ugruntowanym przez patriotyzm konstytucyjny. Habermas pokłada nadzieje w normatywnej sile prawa działającego zarówno wewnątrz jak i na zewnattrz państwa. To oczywiście w pewien sposób ogranicza suwerenność państwa, jednak zdaniem niemieckiego myśliciela jest to konieczne posunięcie na drodze do urzeczywistnienia dobrze funkcjonującego społeczeństwa światowego ${ }^{49}$.

Zdaniem niemieckiego myśliciela „politycznie ukonstytuowana wspólnota międzynarodowa, godna tego miana, byłaby ukonstytuowana w równej mierze przez państwa jak przez obywateli, albo lepiej: przez obywateli $\mathrm{w}$ ich dwojakiej roli obywateli państwa i obywateli świata”. To oznacza, że wedle pomysłu Habermasa taka wspólnota międzynarodowa powinna mieć pełna demokratyczna legitymizację, a co się $z$ tym wiąże byłaby wspólnota nie tylko państw, ale przede

48 Ibidem, s. $179-182$.

49 J. Habermas, Kryzys Unii Europejskiej $w$ świetle konstytucjonalizacji prawa międzynarodowego. Recz o kondycji i ustroju Europy, [w:] Tegoż, Rzecz o kondycji i ustroju Europy, s. 45-116, tu: 95-116. wszystkim obywateli. Dlatego też u Habermasa można wyczytać, jeszcze nie do końca sprecyzowane próby większej legitymizacji zgromadzenia kontynentalnego, chociażby poprzez powszechne wybory prezydenta Unii Europejskiej, czy też ogólnoeuropejskie referenda $\mathrm{w}$ istotnych sprawach. Takie działania zdaniem Habermasa spowodowałyby większe poczucie więzi i zobowiązywania wśród obywateli takiego ponadnarodowego tworu ${ }^{50}$.

Wydaje się, że celem niemieckiego myśliciela jest to, aby wszyscy obywatele mieli pełen dostęp do debaty publicznej, z czym się wiąże to, że wszelka integracja międzynarodowa (której niemiecki myśliciel jest niewatpliwym zwolennikiem) nie powinna odbywać się kosztem rozwoju i aktywnego uczestnictwa społeczeństwa obywatelskiego. Co ważne, wydaje się, że zdaniem autora Teorii działania komunikacyjnego swój głos w debacie publicznej powinni mięć także fundamentaliści religijni. W interesie liberalnego państwa, zdaniem Habermasa leży umożliwienie głosu w ramach racjonalnej komunikacji każdemu obywatelowi. Religia w tym kontekście nie musi być wyłącznie sfera prywatna. Choć oczywiście osoby wierzace sprawujące jakiekolwiek urzędy publiczne powinny respektować całkowita neutralność wobec różnych wyznañ ${ }^{51}$. Dlatego Habermas chciałby, aby powstała europejska (a najlepiej światowa) sfera publiczna utworzona na wzór sfery wewnątrzpaństwowej, która byłaby wolna od przymusu, a za to oparta na rzeczowych argumentach ${ }^{52}$.

50 J. Habermas, Rawls' Politischer Liberalismus. Replik auf die Wiederaufnahme einer Diskussion, [w:] Tegoż, Nachmetaphysisches Denken II, Berlin 2012 [W języku polskim nieopublikowane, przekład cytowanego fragmentu: A. Romaniuk].

51 A. Dupeyrix, op. cit., s. 216.

$52 \mathrm{~W}$ wywiadzie udzielonym w 2008 roku Habermas analizujac problemy Unii Europejskiej stwierdził, że:„Problemem Europy jest całkowi- 
Podsumowujac, według Habermasa żeby pozbyć się wszelkich, groźnych atawizmów, do których zalicza się także terroryzm, trzeba powrócić do rozumienia polityki jako wymiany komunikacyjnej ukierunkowanej na osiągnięcie racjonalnej ugody. W takimi ujęciu polityka trudna jest do odróżnienia od komunikacji w codziennych interakcjach. W obu przypadkach nie moga dominować kłamstwa, manipulacje i oszustwa, gdyż to wyklucza racjonalna komunikację. Naszym celem powinno być uczynienie komunikacyjnego rdzenia polityki (nazywanej przez Borradori „Demokracją codziennej mowy") bardziej efektywnym ${ }^{53}$.

Kolejnym elementem, który ułatwiłby komunikację międzykulturowa, a także dialog $z$ aktorami terroru jest otwarcie sfery publicznej na wszelkie odmienności - zarówno społeczne, kulturowe, polityczne jak i ekonomiczne. Dzięki temu poczucie wykluczenia $z$ pewnościa uległoby zmniejszeniu. Temu celowi może służyć także koncepcja patriotyzmu konstytucyjnego, która postuluje odejście od rozumienia pojęcia narodu, jako elementu wykluczajacego, a w jego miejsce proponuje otwarty na różnicę naród obywatelski. Habermas już wiele lat temu rozważał problem imigracji i ewentualną możliwość jednoczenia się

ty brak uczestnictwa obywateli w tym jedynym w swoim rodzaju projekcie. Państwa członkowskie oddalały się od demokracji w toku integracji europejskiej. Coraz liczniejsze i coraz ważniejsze decyzje zapadaja w Brukseli, a „w domu” sa najwyżej implementowane do narodowych systemów prawnych. Cały ten proces odbywa się poza wspólna sfera publiczną. Mało kto chce dostrzec ów deficyt demokracji i mało kto rozumie, że dalsze pogłębianie integracji instytucjonalnej jest możliwe wyłącznie razem $z$ obywatelami, a nie przeciwko nim"; J. Habermas, Europę ogarnia pośmiertny bezwład, 27.09.2008, http://www.newsweek.pl/europe-ogarnia-posmiertny-bezwlad,43880,1,1.html [dostęp:

${ }^{53}$ G. Borradori, op. cit., s. 81.
Europy. I co ciekawe na oba problemy miał jedno rozwiazanie - pewna formę patriotyzmu konstytucyjnego. Stał na stanowisku, że „tożsamość politycznej wspólnoty, której nie może naruszyć imigracja, zależy przede wszystkim od zakorzenionych w kulturze politycznej zasad prawnych, a nie od całości jakiejś szczególnej etniczno-kulturowej formy życia". Od ewentualnych przybyszów wymagał jedynie „gotowości dostosowania się do politycznej kultury nowej ojczyzny, bez rezygnacji $z$ rodzimej, określonej kulturowo formy życia" 54 .

Z pewnościa koncepcja Habermasa nie przynosi prostego rozwiazania problemu, jakim bez watpienia sa ataki terrorystyczne. Jednak, co warte podkreślenie niemiecki filozof mimo zmieniających się realiów politycznych i społecznych jest konsekwentny i nie zmienia swoich poglądów (mam na myśli okres po tzw. zwrocie rekonstrukcyjnym). Jego recepta to próba podjęcia prawdziwej permanentnej dyskusji, poprzez chęć zrozumienie perspektywy innego. Teorii Habermasa nie uważam za koncepcję idealistyczna czy utopijna, ale jedynie za próbę odrzucenia skrajnego pesymizmu i obronę opartych na prawach człowieka zasad liberalno-demokratycznych.

\section{Bibliografia}

Bala P., Wielomski A., Prawa człowiekarefleksje krytyczne, „Wrocławskie Studia Erazmiańskie”, Wrocław 2010.

Borradori G., Filozofia $w$ czasach terroru. Rozmowy $z$ Jurgenem Habermasa $i$ Jacques'em Derrida, przeł. A. Karalus, M. Kilanowski, B. Orlewski, red. A. Szahaj, Warszawa 2008.

54 J. Habermas, Obywatelstwo a tożsamość narodowa. Rozważania nad przyszłościa Europy, przeł. B. Markiewicz, Warszawa 1993, s. 34. 
Dupeyrix A., Zrozumieć Habermasa, przeł. M. N. Wróblewska, Warszawa 2013.

Habermas J., Europe ogarnia pośmiertny bezwład, 27.09.2008, http://www.newsweek.pl/europe-ogarnia-posmiertny-bezwlad,43880,1,1.html [dostęp: 12.12.2015].

Habermas J., Faktyczność $i$ obowiazywanie. Teoria dyskursu wobec zagadnień prawa $i$ demokratycznego państwa prawnego, przeł. A. Romaniuk, R. Marszałek, Warszawa 2005.

Habermas J., Obywatelstwo a tożsamość narodowa. Rozważania nad przyszłościa Europy, przeł. B. Markiewicz, Warszawa 1993.

Habermas J., Przyszłość natury ludzkiej. Czy zmierzamy do eugeniki liberalnej?, przeł. M. Łukasiewicz, Warszawa 2003.

Habermas J., Rawls' Politischer Liberalismus. Replik auf die Wiederaufnahme einer Diskussion, [w:] Tegoż, Nachmetaphysisches Denken II, Berlin 2012.

Habermas J., Rzecz o kondycji i ustroju Europy, Łódź 2014.
Habermas J., Uwzględniajac Innego. Studia do teorii politycznej, przeł. A. Romaniuk, Warszawa 2009.

Habermas, Teoria działania komunikacyjnego. Racjonalność działania a racjonalność społeczna, t. 1, przeł. A. M. Kaniowski, przekład przejrzał M. J. Siemek, Warszawa 1999.

Maślanka T., Racjonalność $i$ komunikacja. Filozoficzne podstawy teorii społecznej Jurgena Habermasa, Warszawa 2011.

Schnadelbach H., Próba rehabilitacji animal rationale, przeł. K. Krzemieniowa, Warszawa 2001.

Sepczyńska D., Problematyczny status prawdy $w$ polityce. Strauss - Rawls - Habermas, Kraków 2015.

Szahaj A., Jakubowski M. N. , Filozofia polityki, Warszawa 2008.

Wąsiewski G., Koncepcja „patriotyzmu konstytucyjnego" Jurgena Habermasa. $W$ kręgu poszukiwań modelu ustrojowego Unii Europejskiej, Torun 2010. 